means of combining the follow-up of patients and the early detection of complications with a prospective study of the long-term results of treatment.

This work has been supported in part by a grant from the Medical Research Council to J.C.

We gratefully acknowledge the support and co-operation which is being given to this study by the general practitioners in the north-east of Scotland; the statistical advice from Dr. Gordon Hems; and the help given by Dr. D. Donald and Mr. B. Carrie, who reviewed the histological sections.

Requests for reprints should be addressed to Dr. A. J. Hedley, Therapeutics Unit, Maryfield Hospital, Dundee DD1 4HN.

\section{REFERENCES}

Beling, U., and Einhorn, J. (1961). Acta Radiologica, 56, 275.

Billewicz W 7 (1969). Quarterly fournal of Medicine, 38, 255 Blackburn, G. (1962). Transactions of the Medical Society of London, 78, 105 .

Blomfield, G W., et al. (1959). British Medical fournal, 1, 63

Bonnar, J., Goldberg, A., and Smith, J. A. (1969). Lancet, 1, 457.

Bowers, R. F. (1966). American Surgeon, 32, 89

Bowley, A., Hedley, A. J., and Young, A. C. (1969). Unpublished.

Bronsky, D., Kiamko, R. T., and Waldstein, S. S. (1968). Archives of Internal Medicine, 121, 113 .

Clark, F., and Horn, D. B. (1965). Fournal of Clinical Endocrinology and Metabolism, 25, 39.

Crile, G., and McCullagh, E. P. (1951). Annals of Surgery, 134, 18

Crooks, J. (1965). In Current Topics in Thyroid Research edited by C. Cassano and M. Andreoli, p. 1208. New York, Academic Press.
Crooks, J., Wayne, E. J., and Robb, R. A. (1960). Lancet, 1, 397.

Farell, L. P., and Richmond, M. H. (1961). Clinica Chimica Acta, 6, 620

Green, M., and Wilson, G. M. (1964). British Medical fournal, 1, 1005 Greene, R. (1951). Fournal of Endocrinology, 7, 1.

Greig, W. R. (1965). Fournal of Clinical Endocrinology and Metabolism, 25,1411 .

Greig, W. R., Boyle, I. T., and Boyle, J. A. (1967). Diagnosis of Thyroid Disorders, using Radioactive Iodine. Amersham, Radiochemical Centre.

Hedley, A. J., Scott, A. M., Weir, R. D., and Crooks, J. (1970). British Medical fournal, 1

Hobbs, J. R., Bayliss, R. I. S., and Maclagan, N. F. (1963). Lancet, 1, 8. Levitt, T. (1951). Lancet, 2, 957

McLarty, D. G., Alexander, W. D., Harden, R. McG., and Clark, D. H (1969). British Medical fournal, 3, 200.

McNeill, A. D., and Thompson, J. A. (1968). British Medical fournal, 3, 643.

Murley, R. S., and Rigg, B. M. (1968). British fournal of Surgery, 55,

Nofal, M. M., Beierwaltes, W. H., and Patno, M. E. (1966). fournal of the American Medical Association, 197, 605.

Painter, N. S. (1960). British fournal of Surgery, 48, 291.

Philp, J. R. (1966). Postgraduate Medical fournal, 42, 437.

Philp, J. R., Duthie, M. B., and Crooks, J. (1968). Lancet, 2, 1336.

Plested, W. G., and Pollock, W. F. (1967). Archives of Surgery, 94, 517.

Porter, A. M. W. (1969). British Medical fournal, 1, 218.

Reeve, T. S. (1964). Fournal of the College of Radiologists of Australasia 8, 104 .

Riddell, V. (1962). British fournal of Surgery, 49, 465.

Roy, A. D., Allan, J., and Harden, R. McG. (1967). Lancet, 2, 684.

Whitesell, F. B., and Black, B. M. (1949). Fournal of Clinical Endoc rinology and Metabolism, 9, 1202.

Wilson, G. M. (1967). In Symposium of Thyroid Disease and Calcium Metabolism, p. 51. Edinburgh, Royal College of Physicians.

\title{
Amniotic Fluid Cells; Prenatal Sex Prediction and Culture
}

\author{
M. M. NELSON, ${ }^{*}$ M.B., M.R.C.P.ED., D.C.H; A. E. H. EMERY,* M.D., M.SC., PH.D., M.R.C.P.ED.
}

$S^{u}$ ummary : Sex chromatin studies were carried out on small amounts of amniotic fluid obtained by amniocentesis or from intact amniotic sacs removed at hysterotomy. Provided that satisfactory preparations were obtained the accuracy of fetal sexing was $87 \%$. Nevertheless, in the management of a pregnancy in which there is a risk of a serious $\mathrm{X}$-linked recessive disorder, repeat amniocentesis may be necessary to ensure satisfactory specimens.

Of 90 samples of fluid cultured, satisfactory growth was obtained in 49; the success rate was not increased by the addition of stimulants to the culture medium. It is suggested that between the 13th and the 16th week of pregnancy is the optimum time for amniocentesis to obtain cells for culture, since sufficient cells are then present in a small volume of fluid and therapeutic abortion would still be possible once the results were available.

\section{Introduction}

It is now accepted that the cells present in amniotic fluid are of fetal origin (Votta et al., 1968; Wachtel et al., 1969). The exact source of these cells, however, has not yet been established (Wachtel et al., 1969), though it seems likely that skin and amnion are the major source (Votta et al., 1968).

The cells in the amniotic fluid have become the subject of

\footnotetext{
* Lecturer.

$†$ Professor.

University Department of Human Genetics, Western General Hospital, Edinburgh 4.
}

much interest recently because of the possibilities of antenatal diagnosis (Emery, 1970). Uncultured cells have been used for sex chromatin studies (Amarose et al., 1966) and for enzyme studies (Nadler and Gerbie, 1969). Cultured cells have been studied for chromosome abnormalities (Steele and Breg, 1966; Thiede et al., 1966; Jacobson and Barter, 1967; Valenti and Kehaty, 1969) and for enzymes (Nadler, 1968). Unfortunately the limitations and complications of these techniques have usually received little attention and have not been emphasized.

The present study had two main objects: (1) to determine the accuracy of sex prediction under conditions which obtain in practice-that is, using small amounts of fluid, and (2) to determine the conditions necessary for satisfactory culture of amniotic fluid cells.

\section{Materials and Methods}

This report is based on our findings in the first 200 specimens received in this laboratory. Of these, 143 were obtained by transabdominal amniocentesis during the management of Rh-negative pregnancies, 17 by amniocentesis for other reasons, and $\mathbf{4 0}$ from intact sacs removed at hysterotomy.

At amniocentesis the usual volume obtained was 3 to $10 \mathrm{ml}$. The fluid was collected in sterile plastic universal containers. Specimens were either transferred within one to two hours to the laboratory or, where this was not practicable, they were stored at $4^{\circ} \mathrm{C}$. for up to 18 hours. Sacs obtained at hysterotomy were collected as soon as possible after the operation and as much fluid as could be obtained without contamination with blood was aspirated by syringe from the sac. Specimens from 
distant hospitals were transported in sterile containers but with no special precautions.

Viability Studies.-These were carried out according to the method of Steele and Breg (1966) with $0.4 \%$ trypan blue stain; $0.02 \mathrm{ml}$. of stain and $0.1 \mathrm{ml}$. of unspun fluid were mixed and maintained at $37^{\circ} \mathrm{C}$. for five minutes. The stained and unstained cells were then counted in a haemocytometer. The results were expressed as a total cell count, a viable cell count (unstained cells), and the percentage of viable cells per $\mathrm{ml}$. of fluid.

Sex Chromatin Studies.-One to two $\mathrm{ml}$. of fluid was spun in a centrifuge at 2,500 r.p.m. for 30 minutes. The supernatant was decanted and stored for other studies. The cell button was resuspended in $2 \mathrm{ml}$. of chilled fixative (methanol: acetic acid, $3: 1)$ and the cell suspension allowed to stand at room temperature for 30 minutes and then spun for 10 minutes. The fixative was decanted and the cells were resuspended in 0.25 ml. of fresh fixative. Preparations made from one or two drops of the final suspension were stained with $1 \%$ cresyl violet and examined for sex chromatin bodies (Steele and Breg, 1966).

Estimation of Gestation.-With the method of Gordon and Brosens (1966), one drop of unspun fluid and one drop of $0.1 \%$ Nile blue sulphate stain were mixed on a slide. After two minutes the cells were examined and a count was made of the blue and orange cells.

\section{Results}

Viability Studies.-The viable cell counts in the 153 specimens examined are shown in Fig. 1. The total number of cells per ml. of fluid rises steeply between the 20th and 25th

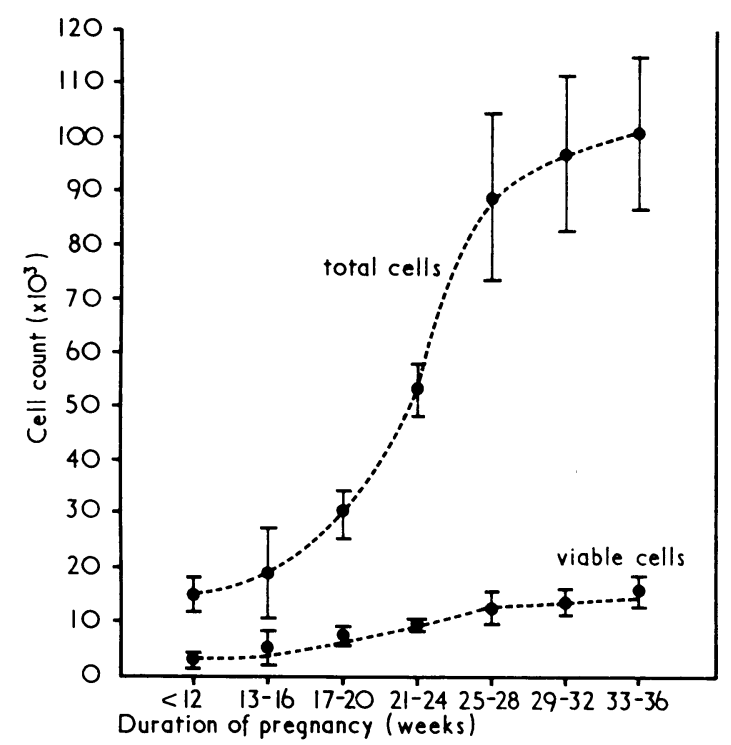

FIG. 1.-Total and viable cells in amniotic fluid. The vertical lines represent the S.E. for each point.

weeks of gestation, the whole curve being S-shaped, but the number of viable cells increases very little during this period.

Sex Chromatin Studies.-The main difficulty in determining fetal sex from sex chromatin studies of amniotic fluid cells is that the nuclei of these cells are often pyknotic or distcrted, or there are insufficient cells on which to base a firm prediction. We examined 190 specimens for sex chromatin bodies-of these the sex of the fetus was not known in 13 cases because the specimen was obtained before abortion by curettage or the fetus was removed and the sex not noted. A further 23 have not yet been delivered, so that the sex was known in 154 of the 190 specimens. Satisfactory preparations were obtained in 104 samples $(67 \%)$, and $91(87 \%)$ of these were correctly sexed. The proportion of satisfactory preparations was somewhat higher in later pregnancy. No relation was found between the accuracy of sex prediction and the period of gestation (Table I). The accuracy of sex prediction in the first half of pregnancy ( 20 weeks) was high when satisfactory preparations were obtained ( 20 out of 22 , or $91 \%$ ). The proportion of unsatisfactory preparations was roughly the same on repeated amniocenteses on the same individual (Table II).

\begin{tabular}{|c|c|c|c|c|c|c|c|c|c|c|}
\hline & \multicolumn{9}{|c|}{ Gestation in Weeks } & \multirow{2}{*}{ Total } \\
\hline & 12 & 13- & $17-$ & $21-$ & $25-$ & $29-$ & 33- & 37- & $40+$ & \\
\hline $\begin{array}{l}\text { Total } \\
\text { Satisfactory } \\
\text { preparations: }\end{array}$ & 12 & 14 & 15 & 17 & 17 & 25 & 40 & 9 & 5 & 154 \\
\hline $\begin{array}{c}\text { No. } \\
\text { oo } \\
\text { Sexed correctly: }\end{array}$ & $\begin{array}{r}5 \\
42 \\
\end{array}$ & $\begin{array}{r}9 \\
64\end{array}$ & $\begin{array}{r}8 \\
53\end{array}$ & $\begin{array}{l}11 \\
65\end{array}$ & $\begin{array}{l}11 \\
65\end{array}$ & $\begin{array}{l}22 \\
88\end{array}$ & $\begin{array}{l}29 \\
72\end{array}$ & $\begin{array}{r}7 \\
78\end{array}$ & $\begin{array}{r}2 \\
40\end{array}$ & $\begin{array}{r}104 \\
67\end{array}$ \\
\hline $\begin{array}{ll}\text { No. } \\
\text { \%o }\end{array}$ & $\begin{array}{r}5 \\
100\end{array}$ & $\begin{array}{r}99 \\
100\end{array}$ & $\begin{array}{r}6 \\
75\end{array}$ & $\begin{array}{r}6 \\
54\end{array}$ & $\begin{array}{r}8 \\
73\end{array}$ & $\begin{array}{l}20 \\
91\end{array}$ & $\begin{array}{l}28 \\
96\end{array}$ & 100 & 100 & $\begin{array}{l}91 \\
87\end{array}$ \\
\hline
\end{tabular}

TABLE II.-Proportion of Satisfactory Preparations and the Accuracy of Sex Prediction in Repeated Amniocenteses

\begin{tabular}{|c|c|c|c|c|c|c|}
\hline \multirow{2}{*}{\multicolumn{2}{|c|}{ Amniocenteses }} & \multirow{2}{*}{ Total } & \multicolumn{2}{|c|}{ Satisfactory Preparations } & \multicolumn{2}{|c|}{ Sexed Correctly } \\
\hline & & & No. & $\%$ & No. & $\%$ \\
\hline $\begin{array}{l}\text { 1st } \\
\text { 2nd } \\
\text { 3rd } \\
4 \text { th } \\
5 \text { th }\end{array}$ & $\begin{array}{ll}\cdots & \ldots \\
\cdots & \cdots \\
\cdots & \cdots \\
\cdots & \ldots\end{array}$ & $\begin{array}{r}22 \\
22 \\
12 \\
8 \\
1\end{array}$ & $\begin{array}{r}13 \\
15 \\
6 \\
6 \\
\end{array}$ & $\begin{array}{l}59 \\
68 \\
50 \\
75 \\
\end{array}$ & $\begin{array}{r}11 \\
14 \\
6 \\
6 \\
-\end{array}$ & $\begin{array}{r}85 \\
93 \\
100 \\
100 \\
\end{array}$ \\
\hline
\end{tabular}

Estimation of Gestation.-The results in 184 specimens stained with Nile blue sulphate are shown in Fig. 2. Though a few orange-staining cells were found in specimens from early pregnancy, the proportion of these cells exceeded $2 \%$ only after mid-pregnancy.

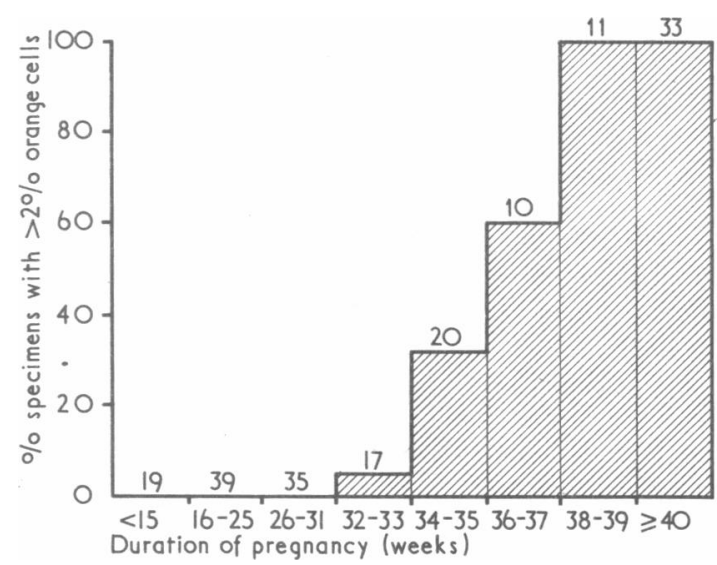

FIG. 2.-Percentage of specimens stained with Nile blue sulphate with more than $2 \%$ orange cells. The numbers of specimens examined at each period of gestation are given.

\section{Amniotic Fluid Cell Culture}

In this laboratory the following method has been found to be the most satisfactory for growing amniotic fluid cells in culture.

A 1-10 ml. aliquot from each specimen is centrifuged at $800-$ 900 r.p.m. for 10 minutes and the supernatant decanted for other studies. The cells are then resuspended in $0.25 \mathrm{ml}$. of 
fetal calf serum, placed in a plastic Petri dish, and covered by a glass coverslip. The cultures are allowed to stand for 20 to 40 minutes at $37^{\circ} \mathrm{C}$., when the medium (F10 from Flow Laboratories, Irvine, Scotland, with $30 \%$ fetal calf serum and antibiotics) is added. The dish is now stored in a sealed container with a $5 \% \quad \mathrm{CO}_{2}$ atmosphere and left undisturbed for seven days. The medium is then changed, and the process is repeated after a further seven days, thereafter being repeated at intervals of three to four days. Subculture is performed when required, using $0.25 \%$ trypsin to detach the cells from the dish.

Cultures were set up from the last 90 of the first 200 samples received in this laboratory, and 49 of them gave satisfactory growth. Satisfactory growth is here defined as the presence of growing cells within three weeks of a culture being set up. In 21 cases there were obvious reasons to account for failure: infection, contamination with maternal blood, and technical errors. In one culture a piece of tissue thought to be maternal skin was noted. There was no growth from this tissue, and nothing similar has been observed in any other preparation. The remaining 68 cases were analysed to ascertain what factors might be responsible for determining the success or otherwise of a particular culture.

There was no significant difference between the proportion of successful cultures from samples obtained before 20 weeks (17 out of 24 , or $71 \%$ ) and those obtained after 20 weeks' gestation (32 out of 44 , or $73 \%$ ) (Table III).

TABLE III.-Average Total Cell and Viable Cell Counts and Percentage Viable Cells per Inoculum and Subsequent Success in Culture in Samples Obtained Before and After 20 weeks' Gestation

\begin{tabular}{|c|c|c|c|c|}
\hline & \multicolumn{2}{|c|}{ Before 20 Weeks } & \multicolumn{2}{|c|}{ After 20 Weeks } \\
\hline & Successful & Unsuccessful & Successful & Unsuccessful \\
\hline $\begin{array}{l}\text { No. of specimens } \\
\text { Volume of fluid* (ml.).. } \\
\text { Average total cells } \\
\text { Average viable cells } \\
\text { Viable cells }(\%)\end{array}$ & $\begin{array}{c}17 \\
6 \cdot 5 \\
100,700 \\
24,300 \\
24\end{array}$ & $\begin{array}{c}7 \\
9 \cdot 0 \\
69,250 \\
19,300 \\
28\end{array}$ & $\begin{array}{c}32 \\
3 \cdot 0 \\
169,800 \\
25,400 \\
15\end{array}$ & $\begin{array}{c}12 \\
3 \cdot 0 \\
303,700 \\
31,300 \\
10\end{array}$ \\
\hline
\end{tabular}

*Average volume of fluid centrifuged to provide the cells used in setting up a particular culture.

The cell count per ml. of fluid and the amount of fluid spun in each instance were used to determine the cell count per inoculum per dish. There was no significant difference between the total and the viable cell counts, and the percentage viable cells per inoculum in successful and unsuccessful cultures before or after 20 weeks' gestation (Table III).

\section{Attempts to Stimulate Cell Growth}

In attempts to stimulate cell growth we have added to the basic culture medium the following:

(a) Aqueous extract of human pituitary- $0.05 \mathrm{ml}$. of extract per $\mathrm{ml}$. of medium. The intact pituitary was obtained at necropsy, washed in balanced salt solution, and as much of the fibrous tissue removed as possible. The remaining tissue was ground up and an aqueous extract prepared which was sterilized by millipore filtration. The $0.05 \mathrm{ml}$. of extract represented the soluble material derived from $1.75 \mathrm{mg}$. of pituitary tissue.

(b) Ethinyloestradiol: Aqueous extract was added to the medium in the proportion of $0.0005 \mathrm{mg} . / \mathrm{ml}$.

(c) Methyl progesterone: Aqueous extract was added in the proportion of $0.05 \mathrm{mg} . / \mathrm{ml}$. medium.

(d) Medium taken from a rapidly growing culture was added in a 1:1 proportion to the medium used in setting up the cell cultures.

The effect of setting up cultures on a collagen substrate was also studied. None of these attempts, however, has produced any obvious increase in growth rate or led to greater success in establishing satisfactory cultures.

\section{Discussion}

The results of the present study indicate that the accuracy of sex prediction, based on sex chromatin studies on amniotic fluid cells, is greater than $90 \%$ provided that the material is satisfactory. Unfortunately about one-third of specimens were not considered satisfactory enough for a firm prediction of fetal sex to be made. It has been found that the proportion of satisfactory preparations tends to increase throughout pregnancy, but, provided a preparation is satisfactory, fetal sex prediction is at least $90 \%$ accurate in early pregnancy. These results would therefore suggest that in the management of a pregnancy where there is a risk that a male fetus might have a serious X-linked recessive disorder, such as Duchenne muscular dystrophy, it is important that those concerned should realize that repeat amniocentesis may be necessary. The results of the study also indicate that the proportion of unsatisfactory preparations is roughly the same on repeated amniocenteses on the same individual.

When selective abortion is being considered in the management of a pregnancy where there is a high risk of producing an infant with a hereditary disorder or congenital abnormality, the establishment of the exact duration of pregnancy is of importance. Though the Nile blue sulphate staining technique is of some use in estimating gestational age in late pregnancy (Gordon and Brosens, 1966), the results of the present study confirm that this technicue cannot be used in estimating gestational age in early pregnancy (Chan et al., 1969).

The successful growth of amniotic fluid cells in culture is now well established. In this laboratory successful growth has been observed in about $70 \%$ of specimens obtained before 20 weeks' gestation even when only small volumes of fluid (less than $10 \mathrm{ml}$.) have been used. Valenti and Kehaty (1969) reported an $80 \%$ success rate in specimens before 20 weeks, but the average amount of fluid used in their cultures was $33 \mathrm{ml}$., and in no case was it less than $10 \mathrm{ml}$. Nadler (1968) reported $83 \%$ success with "usually 5-10 ml." Using a slightly different technique, Jacobson and Barter (1967) obtained a 64\% success rate with 1-2 ml. of fluid. Data given by other authors (Steele and Breg, 1966; Klinger and Miller, 1968) do not allow similar comparisons to be made.

There remains the problem, however, of the length of time required before sufficient cells can be harvested for biochemical studies-this is at present about four to six weeks. When culture of these cells is to be used as a diagnostic procedure to be followed by therapeutic abortion this long culture time is a serious handicap.

Under existing conditions of growth a balance must be reached between obtaining fluid as early as possible in pregnancy and ensuring that the number and quality of cells present in the specimen will be such as to produce growth. Fluid obtained from abortion as early as eight weeks has been successfully cultured, but there are problems in obtaining liquor as early as this in pregnancies which may be required to continue to term. We have established that successful cultures may be cbtained from as little as 2 to $3 \mathrm{ml}$. of fluid; removal of this amount of liquor early in pregnancy should have little adverse affect, but at this early period the number of cells present in the fluid is too low to ensure an ideal inoculum. On average at least twice as much fluid is required in the first half of pregnancy in order to obtain successful growth (Table III). It seems likely, from our data, that between the 13th and 16th weeks is the optimum time for amniocentesis, because at this time a small volume of fluid containing a satisfactory number of cells can be obtained. Allowing six weeks in culture this would permit therapeutic abortion to be carried out at 20 to 22 weeks, about six weeks later than the ideal time for the obstetrician. If the culture time required could be consistently reduced to two to three weeks a compromise could be reached.

Investigations are being directed towards increasing the 
number of cell colonies which appear in the cultures. We found that the number of colonies never exceeds 10 even when the viable cell count is high. This may be because the staining test of viability does not reflect the growth potential of the cell or because the non-viable cells present exert some adverse effect on the growth of the viable cells. At present we have not been able to identify which cells do grow, though both fibroblasts and epithelioid cells are present in the cultures; the former are the more vigorous, and they dominate in subcultures.

Adjustment of the total number of cells in the inoculum is desirable as either overcrowded or widely separated cells do not grow rapidly. It is difficult to establish the ideal number, however, as our data do not indicate any clear relation between cell number and success in culture (Table III).

Different methods of setting up the cultures are currently being investigated, since the most crucial stage appears to be the initiation of growth; maintenance of a cell line once established presents much less of a problem.

When it is not possible to obtain amniotic fluid cells for culture, studies may be carried out on cther tissues of fetal origin. In our laboratory randomly selected specimens of amnion have been cultured from explants (Smith et al., 1969) with a $95 \%$ (19 out of 20 specimens) success rate. Similarly cultures of cord explants have also been successful (13 out of 13). Subcultures of amnion and cord have been possible by about the 15th day of culture. Placental tissue has nct been so easy to grow, but no serious attempt was made to overcome the difficulties in view of the ease of culture of othcr tissues. Four specimens of chorion all grew within eight days.

It may be that biopsies of fetal skin, membranes, or even fetal blood would be easier material to handle in the laboratory as aids to antenatal diagnosis, but the problems of obtaining these specimens are at present very great.

We should like to express our gratitude to all the obstetricians who kindly sent us specimens of amniotic fluid, particularly Dr. J. G. Robertson, Dr. J. Scrimgeour, and Dr. G. Gordon, and would like to thank Miss E. MacEntire for technical assistance. This work was supported by a grant from the Secretary of State for Scotland.

\section{REFERENCES}

Amarose, A. P., Wallingford, A. J., and Plotz, E. J. (1966). New England fournal of Medicine, 275, 715 .

Chan, W. H., Willis, J., and Woods, J. (1969). fournal of Obstetrics and Gynaecology of the British Commonwealth, 76, 193.

Emery, A. E. H. (1970). In Modern Trends in Human Genetics. London, Butterworths. In press.

Gordon, H., and Brosens, I. (1966). Obstetrics and Gynecology, 30, 652.

Jacobson, C. B., and Barter, R. H. (1967). American fournal of Obstetrics and Gynecology, 99, 795.

Klinger, H. P., and Miller, O. J. (1968). In Diagnosis and Treatment of Fetal Disorders, p. 72. New York, Springer.

Nadler, H. L. (1968). Pediatrics, 42, 912.

Nadler, H. L., and Gerbie, A. B. (1969). American fournal of Obstetrics and Gynecology, 103, 710

Smith, M., MacNab, J., and Ferguson-Smith, M. A. (1969). Obstetrics and Gynecology, 33, 313.

Steele, M. W., and Breg, W. R., jun. (1966). Lancet, 1, 383.

Thiede, H. A., Creasman, W. T., and Metcalfe, S. (1966). American fournal of Obstetrics and Gynecology, 94, 589.

Valenti, C., and Kehaty, T. (1969). Fournal of Laboratory and Clinical Medicine, 73, 355 .

Votta, R. A., Bobrow de Gagneten, C., Parada, O., and Giulietti, M. (1968). American fournal of Obstetrics and Gynecology, 102, 571 .

Wachtel, E., Gordon, H., and Olsen, E. (1969). fournal of Obstetrics and Gynaecology of the British Commonwealth, 76, 596.

\title{
Assessment of Paracervical Nerve Block Anaesthesia during Labour
}

\author{
P. J. MURPHY,* M.B., M.A.o., M.R.C.o.G. ; J. D. WRIGHT, $†$ M.B., M.R.c.o.G., \\ T. B. FITZGERALD, $\ddagger$ M.B., F.R.C.S.ED., F.R.C.o.G.
}

British Medical fournal, 1970, 1, 526-529

\begin{abstract}
Cummary: An assessment of paracervical nerve tlock anaesthesia was made in 118 women during labour using $0.5 \%$ bupivacaine with 1:200,000 parts of adrenaline added. The 82 multiparae were each given a single block and the 36 primigravidae a continuous block to try to provide the sole means of analgesia throughout the first stage of labour.

Only $48 \%$ of the primigravidae required no other form of analgesia, as against $72 \%$ of the multiparae.

Complications included a $17 \%$ incidence of maternal haemorrhage during insertion of the continuous needle, an overall fetal bradycardia rate of $11 \%$, and two perinatal deaths following single paracervical block. It is concluded that the use of continuous paracervical block should be discontinued, and that amide-type local anaesthetic agents should not be used for single paracervical block.
\end{abstract}

* Clinical Tutor.

†Residential Surgical Officer.

St. Mary's Hospitals for Women and Children, Manchester 13.

\section{Introduction}

The use of paracervical nerve block anaesthesia to provide analgesia in labour was first described by Gellert (1926). Since then several workers have provided evidence of its efficacy (Freeman et al., 1956; Davis et al., 1962; Cooper and Moir, 1963). A wider usage in obstetric practice might have been expected but for the short duration of analgesia provided by the local anaesthetic agents available.

Two methods of increasing the duration of analgesia without the need for repeated vaginal puncture have been reported. Firstly, the recently introduced local anaesthetic agent bupivacaine has been shown to provide analgesia for three to four hours after a single paracervical nerve block (Kuah and Yates, 1967; Cooper et al., 1968; Gudgeon, 1968; Picton 1969). Secondly, the use of continuous block which was described by Tafeen et al. (1966). This enables repeated injections of local anaesthetic agent to be administered through fine precurved polyvinyl catheters inserted and retained in the paracervical spaces.

The purpose of this study was to determine whether bupivacaine could be used to provide the sole means of 